\title{
MALIGNANCY RISK WITH ATYPIA OF UNDETERMINED SIGNIFICANCE FINDING ON THYROID NODULE FNA: CLINICAL EXPERIENCE FROM A TERTIARY INSTITUTION
}

\author{
Josip Staničić, Davor Kust, Neven Mateša and Zvonko Kusić \\ Department of Oncology and Nuclear Medicine, Sestre milosrdnice University Hospital Centre, Zagreb, Croatia
}

\begin{abstract}
SUMMARY - The Bethesda System for Reporting Thyroid Cytopathology from 2009 introduced a new category in thyroid nodule fine-needle aspiration (FNA) findings named atypia of undetermined significance (AUS), which usually appears in around 5\% of FNA findings. Our study aimed to assess the utility of AUS finding in determining the risk of malignancy in thyroid nodules. In our study, 160 patients with AUS finding on initial FNA were regularly followed-up. Total and specific malignancy rates were calculated after receiving histopathologic confirmation or histopathologic/cytologic exclusion of malignancy. Eventually $80(50 \%)$ patients were referred to surgery, with malignancy rate of $37.5 \%$ on histopathology. Another 52 (32.5\%) patients were confirmed to have benign nodules on repeat FNA. After combining results obtained from histopathologic reports with those obtained from cytologic follow-up, total malignancy rate was $22.72 \%$. However, malignancy was confirmed in only one (5.26\%) of 19 patients with AUS finding on repeat FNA with surgical and histopathologic follow-up. In conclusion, FNA is an extremely useful tool for clinicians to discriminate patients to be referred to surgery and those that can be followed-up safely without the need for further invasive procedures.
\end{abstract}

Key words: Biopsy, fine-needle; Thyroid nodule; Thyroid neoplasms; Cytodiagnosis; Adenocarcinoma, follicular

\section{Introduction}

Since its introduction in the 1960s, fine-needle aspiration biopsy (FNA) has become an indispensable tool for clinicians in thyroid cancer diagnostics. It has the ability to pinpoint suspicious thyroid nodules accurately for malignancy, but also to almost completely exclude the possibility of malignancy in case of benign finding ${ }^{1}$. The Bethesda System for Reporting Thyroid Cytopathology (BSRTC) from 2009 introduced a new category in thyroid nodule FNA findings named atypia of undetermined significance (AUS) ${ }^{2}$. In 2012, the Croatian Society for Clinical Cytology, on the basis of

Correspondence to: Josip Staničic, $M D$, Department of Oncology and Nuclear Medicine, Sestre milosrdnice University Hospital Centre, Vinogradska c. 29, HR-10000 Zagreb, Croatia

E-mail: josip.stanicic@kbcsm.hr

Received May 5, 2017, accepted November 16, 2018 data reported in the literature and own experience, implemented the following 4-tiered diagnostic scheme: non-diagnostic category, benign lesions, indeterminate lesions, and malignant neoplasm category ${ }^{3}$. The category of indeterminate lesions comprises a large spectrum of lesions with cytologic features more or less suggestive of but not diagnostic for malignancy. More common in this category are AUS, follicular neoplasm, Hürthle cell neoplasm and suspicious of papillary carcinoma. Individual approach is recommended and, in most cases, clinical data and ancillary methods determine further treatment.

The term AUS is reserved for specimens that contain cells (follicular, lymphoid, or other) with architectural and/or nuclear atypia that is not sufficient to be classified as suspicious of follicular neoplasm, suspicious of malignancy, or malignant ${ }^{2}$. Most AUS cases are based on follicular cell atypia, but in rare cases, the 
Table 1. Follow-up of patients after AUS finding on initial FNA

\begin{tabular}{|l|l|l|l|l|}
\hline \multirow{2}{*}{ Repeat FNA after initial AUS } & \multirow{2}{*}{ No. of patients } & \multirow{2}{*}{ Referred to surgery } & \multicolumn{2}{|l|}{ Histopathologic report } \\
\cline { 5 - 6 } & & & Malignant & Benign \\
\hline Not performed & $35(21.88 \%)$ & $35(100 \%)$ & $12(34.29 \%)$ & $23(65.71 \%)$ \\
Salignant & $11(6.88 \%)$ & $11(100 \%)$ & $10(90.91 \%)$ & $1(9.09 \%)$ \\
AUspicious of malignancy & $11(6.88 \%)$ & $11(100 \%)$ & $6(54.55 \%)$ & $5(45.45 \%)$ \\
Follicular neoplasm & $45(28.13 \%)$ & $19(40.91 \%)$ & $1(5.26 \%)$ & $18(94.74 \%)$ \\
Benign & $6(3.75 \%)$ & $4(66.67 \%)$ & $1(25 \%)$ & $3(75 \%)$ \\
\hline Total & $52(32.5 \%)$ & 0 & & \\
\hline
\end{tabular}

AUS = atypia of undetermined significance; FNA = fine-needle aspiration

Table 2. Total malignancy rate in patients after initial AUS FNA finding

\begin{tabular}{|c|c|c|c|}
\hline $\begin{array}{l}\text { Patients with initial } \\
\text { AUS FNA finding }\end{array}$ & Total & Male & Female \\
\hline $\begin{array}{l}\text { Malignant } \\
\text { (all with histologic } \\
\text { confirmation) }\end{array}$ & $30(22.72 \%)$ & 2 & 28 \\
\hline $\begin{array}{l}\text { Benign (including } \\
\text { patients with clinical } \\
\text { follow-up) }\end{array}$ & $102(77.28 \%)$ & 3 & 99 \\
\hline Total & 132 & 5 & 127 \\
\hline
\end{tabular}

AUS $=$ atypia of undetermined significance; FNA = fine-needle aspiration

AUS designation may be appropriate for a non-follicular and even non-epithelial atypia. According to literature data, the risk of malignancy in these nodules ranges from $5 \%$ to $20 \% \%^{2,4,5,6}$.

Our study aimed to assess the utility of AUS finding in determining the risk of malignancy in thyroid nodules. This type of study has not yet been performed in Croatia.

\section{Patients and Methods}

A total of 160 patients referred from Department of Oncology and Nuclear Medicine, Sestre milosrdnice University Hospital Centre, Zagreb, Croatia, with AUS finding in one of their thyroid nodules were regularly followed-up. During their regular follow-up visits, thyroid hormones, ultrasonography (US) and, in most cases, repeat FNA were performed. Patients with benign finding on repeat FNA were classified as be- nign; those with malignant finding or finding suspicious of malignancy were immediately referred to head and neck surgeon for total thyroidectomy. Patients with AUS finding on multiple repeat FNAs were referred to further follow-up. In these cases, US finding was especially important for being able to determine the increase in the respective nodule size and changes in its morphology that could indicate malignant transformation.

After the classification was completed, the rate of malignant nodules and the rate of nodules suspicious of malignancy after repeat FNA in our sample was calculated and compared to data from the literature. In addition, the rate of benign findings on repeat FNA was calculated, as well as the rate of continued AUS findings on repeat FNA. After the surgery was performed on patients with suspicious nodules, the rate of malignancy was calculated for all groups of patients and combined with the data obtained on follow-up to yield a complete report of the risk of malignancy in patients with AUS finding in thyroid nodules.

\section{Results}

A total of 3550 patients had one or more FNAs performed on one or more thyroid nodules at our Department from 2011 until 2015. Of these, 187 patients (15 male and 171 female) had an AUS finding on FNA (5.26\%). During that period, 27 patients were lost from follow-up. Most of the patients were referred to repeat FNA, but some were immediately referred to surgery without repeat FNA, mostly due to nodule size and suspicious morphology on US. Patients with malignant finding or finding suspicious of malignancy 
on repeat FNA were immediately referred to surgery. Most of the patients with AUS finding on repeat FNA went on to be monitored with US for nodule size and morphology. However, even some of those patients were referred to surgery, mostly due to the size of their nodules. Eventually, 80 (4 male and 76 female) patients with AUS finding on initial FNA were referred to surgery, with a malignancy rate of $37.5 \%$ on histopathology. Detailed summary of patient follow-up is shown in Table 1.

After coupling results obtained from histopathologic reports with those obtained from clinical followup, and after excluding 28 patients with still indeterminate lesions on repeat FNA, the malignancy rate for 132 patients with initial AUS finding on FNA was $22.72 \%$. Detailed summary is shown in Table 2.

\section{Discussion}

Thyroid nodules are the most common thyroid pathology, with almost $50 \%$ of the population affected ${ }^{7}$. The principal issue with thyroid nodules is the possibility of malignancy in some of these nodules. The introduction of US and FNA gave the clinicians an indispensable tool in thyroid cancer diagnostics, but also created some problems, which include over-diagnostics and false-positive results, which lead to unnecessary thyroidectomy ${ }^{8}$. Trying to further improve the diagnostic criteria, a group of most prominent cytologists introduced BSRTC as a new classification in 2009, which included a new category of AUS comprising all those findings not easily included into benign, suspicious or malignant categories. This category principally includes cases with nuclear and/or architectural atypia, which are not sufficient to mark them as malignant neoplasms ${ }^{2}$.

Generally, the AUS finding accounts for 3\% to $10 \%$ of all thyroid FNA findings ${ }^{4,5,9}$. Our experience is generally in line with data from the literature, with $5.26 \%$ of thyroid FNAs resulting in AUS. Data from the literature indicate that malignancy risk in nodules with AUS ranges from $15 \%$ to $25 \% 5,10$, but it usually includes only patients with histologic follow-up. In our study, $50 \%$ of patients with initial AUS FNA finding were eventually referred to surgery, and malignancy rate among them was $37.5 \%$. Thirty five (21.88\%) of 160 patients were immediately referred to surgery without further diagnostic follow-up, mainly due to the size of the nodules or their morphology on US. Eventually, most of the patients were proven to have benign nodules, or continued to have AUS finding on repeat FNA. However, malignancy or suspicious malignancy on repeat FNA was found in $22(17.6 \%)$ patients with initial AUS FNA finding, prompting immediate surgery. Eventually, 30 out of 132 patients with AUS finding on initial FNA and with surgical/ clinical follow-up were proven to have malignant thyroid nodules, with a malignancy rate of $22.72 \%$. Interestingly, malignancy was confirmed in only one (5.26\%) of 19 patients with AUS finding on repeat FNA with surgical and histopathologic follow-up.

What does an AUS finding on FNA of thyroid nodule tell the clinician in regular practice? It certainly raises suspicion of malignancy for the nodule in question and urges the clinician to follow-up the patient and order repeat FNA of the nodule. Many of those nodules on repeat FNA are classified as benign nodules, but a small percentage fall into malignant category and require surgery. Dilemma remains on how to proceed with patients whose nodules yield an AUS finding even on repeat FNA.

Our practice in these cases is to repeat FNA for two more times. If both FNAs result in AUS finding, we continue to follow-up these patients with US that can precisely monitor nodule size and morphology and report any changes with high specificity prompting another repeat FNA, primarily since, as our study revealed, the risk of malignancy in these nodules remains very low. However, since FNA is not the only criterion in determining whether surgery is needed, it is up to the clinician to resolve how to proceed in these cases, where his experience can often be the decisive factor.

\section{Conclusion}

Fine-needle aspiration is an extremely useful tool for clinicians to discriminate patients to be referred to the surgeon. In our study, we found that AUS finding on FNA showed a general risk of malignancy in thyroid nodule of $22.72 \%$. This figure is not insignificant and prompts further diagnostic follow-up by the clinician to determine which patients should be referred to surgery, and which can be followed-up safely without the need for further invasive procedures, especially since in our study, malignancy was confirmed in only 
$5.26 \%$ of patients with AUS finding on repeat FNA with surgical and histopathologic follow-up.

\section{References}

1. Hamberger B, Gharib H, Melton LJ, Goellner RJ, Zinsmeister A. Fine-needle aspiration biopsy of thyroid nodules. Am J Med. 1982 Sep 1;73(3):381-4.

2. Cibas ES, Ali SZ. The Bethesda System for Reporting Thyroid Cytopathology. Thyroid. 2009 Nov;19(11):1159-65. doi: 10.1089/thy.2009.0274.

3. Mateša N, Knežević-Obad A, Ostović KT, Kardum-Skelin I, Moslavac S, Vasilj A, et al. Croatian Society for Clinical Cytology guidelines for thyroid cytology. Lijec Vjesn. 2012;134: 203-7.

4. Crowe A, Linder A, Hameed O, Salih C, Roberson J, Gidley J, et al. The impact of implementation of the Bethesda System for Reporting Thyroid Cytopathology on the quality of reporting, "risk" of malignancy, surgical rate, and rate of frozen sections requested for thyroid lesions. Cancer Cytopathol. 2011 Oct 25;119(5):315-21. doi: 10.1002/cncy.20174.

5. Bongiovanni M, Spitale A, Faquin WC, Mazzucchelli L, Baloch ZW. The Bethesda System for Reporting Thyroid Cy- topathology: a meta-analysis. Acta Cytol. 2012;56(4):333-9. doi: 10.1159/000339959

6. Arul P, Akshatha C, Masilamani S. A study of malignancy rates in different diagnostic categories of the Bethesda System for Reporting Thyroid Cytopathology: an institutional experience. Biomed J. 2015 Dec;38(6):517-22. doi: 10.1016/j.bj.2015.08.001

7. Staničić J, Prpić M, Jukić T, Borić M, Kusić Z. Thyroid nodularity - true epidemic or improved diagnostics. Acta Clin Croat. 2009;48(4):413-8.

8. Canberk S, Firat P, Schmitt F. Pitfalls in the cytological assessment of thyroid nodules. Turkish Journal of Pathology [Internet]. 2015 [cited 2016 May 19]; Available from: http://www. turkjpath.org/doi.php?doi=10.5146/tjpath.2015.01312

9. Bongiovanni M, Crippa S, Baloch Z, Piana S, Spitale A, Pagni $\mathrm{F}$, et al. Comparison of 5-tiered and 6-tiered diagnostic systems for the reporting of thyroid cytopathology: a multi-institutional study. Cancer Cytopathol. 2012 Apr 25;120(2):117-25. doi: 10.1002/cncy.20195

10. Straccia P, Rossi ED, Bizzarro T, Brunelli C, Cianfrini F, Damiani D, et al. A meta-analytic review of the Bethesda System for Reporting Thyroid Cytopathology: has the rate of malignancy in indeterminate lesions been underestimated? Cancer Cytopathol. 2015 Dec;123(12):713-22. doi: $10.1002 /$ cncy.21605

Sažetak

\section{RIZIK MALIGNITETA U ČVORU ŠTITNJAČE KOD NALAZA ATIPIJE NEODREĐENE ZNAČAJNOSTI NA CITOLOŠKOJ PUNKCIJI: KLINIČKO ISKUSTVO IZ TERCIJARNE USTANOVE}

\section{J. Staničič, D. Kust, N. Mateša i Z. Kusić}

Kroz Sustav Bethesda za citološku analizu štitnjače 2009. godine uvedena je nova kategorija u nalazima citološke punkcije čvorova u štitnjači pod nazivom atipija neodređene značajnosti (AUS), koja se obično pojavljuje u oko $5 \%$ nalaza. Ovom studijom žljeli smo procijeniti korist nalaza AUS u određivanju rizika maligniteta u čvorovima štitnjače. U našoj studiji pratili smo ukupno 160 bolesnika s nalazom AUS na početnoj citološkoj punkciji. Nakon patohistološke potvrde ili citološkog/patohistološkog isključivanja maligniteta u navedenom čvoru izračunali smo ukupni i specifični rizik maligniteta. Ukupno je 80 (50\%) bolesnika bilo upućeno na operacijski zahvat, od čega je ukupno 37,5\% imalo patohistološki potvrđen rak štitnjače. Benigni čvorovi bili su dokazani ponovljenom citološkom punkcijom u još 52 (32,5\%) bolesnika. Ukupni udio malignih čvorova nakon udruživanja rezultata patohistologije s rezultatima ponovljene citološke punkcije iznosio je $22,72 \%$. Ipak, samo je jednom $(5,26 \%)$ od 19 bolesnika koji su bili poslani na operaciju nakon višestrukog nalaza AUS na ponovljenim punkcijama patohistološki potvrđen karcinom štitnjače. Citološka punkcija je izrazito koristan dijagnostički postupak za odabir bolesnika koje bi trebalo uputiti na operaciju štitnjače nasuprot onima koji se mogu sigurno pratiti bez rizika provođenja invazivnih zahvata.

Ključne riječi: Biopsija tankom iglom; Tireoideja, čvor; Tireoidni tumori; Citodijagnostika; Adenokarcinom, folikularni 